\title{
Az online oktatás tapasztalatai gyakorló pedagógusok és egyetemi hallgatók szemszögéből
}

\author{
A virtuális osztálytermek szerepe a tanításban
}

\author{
Miskei-Szabó Réka \\ Eötvös Loránd Tudományegyetem Tanitó- és Óvóképzö Kar \\ Idegen Nyelvi és Irodalmi Tanszék
}

\begin{abstract}
Absztrakt
Jelen tanulmány pedagógusok és egyetemi hallgatók online oktatással kapcsolatos tapasztalatait vizsgálja a 2020/2021-es koranavírus-járvány miatti korlátozások idején. A tanulmány egy kismintás kutatáson alapszik. Az interjúkból nyert adatok betekintést engednek többek között az online oktatással kapcsolatos tapasztalatokba, a virtuális osztálytermek müködésébe a megismert platformok és eszközök jelenléti oktatásban betöltött jövőbeni szerepébe.
\end{abstract}

Kulcsszavak: Covid19, online oktatás, nyelvoktatás, virtuális osztálytermek

\section{Bevezetés}

Jelen tanulmány fókuszát a 2020/2021-es Covid-járvány következtében bevezetett online oktatással, különös tekintettel a virtuális osztálytermek használatával kapcsolatos tapasztalatok képzik. A tanulmány egy kismintás pilotkutatáson alapul, amely 2021 tavaszán készült öt gyakorló tanító és öt negyedéves tanító szakos hallgató bevonásával. A járvány gazdasági, pénzügyi és egészségügyi vetületei mellett a pandémia oktatásra gyakorolt hatásra is nagy érdeklődésre tart számot. Ezt bizonyítja a számtalan megjelent tanulmány, amely mind a közoktatásban, mind a felsőoktatásban bekövetkezett változásokat és megoldási lehetőségeket vizsgálja. Jelen tanulmány további kutatások előkészítését szolgálja, mivel igyekszik feltérképezni azokat a hallgatói és tanítói tapasztalatokat, élményeket és attitűdöket, amelyek befolyásolhatják a koronavírus utáni oktatás jellemzőit. Ezenkívül a tanulmány igyekszik rámutatni a felsőoktatás és a közoktatás közötti kapcsolódási pontokra a végzős hallgatók rendkívüli gyakorlatuk során gyüjtött tapasztalatai által. A kis elemszám miatt az eredmények természetesen nem tesznek lehe- 
tővé messzemenő következtetéseket, de remélhetőleg megfelelő kiindulási alapként szolgálnak az ELTE TÓK Idegen Nyelvi és Irodalmi Tanszék által tervezett nagyobb volumenü kutatáshoz. Fontos még kiemelni, hogy jelen tanulmány elsősorban a nyelvtanítással kapcsolatos lehetőségeket vizsgálja. A megkérdezett pedagógusok és hallgatók mindegyike német müveltségterületen vagy nemzetiségi oktatásban dolgozik

\section{Az online oktatás az eddigi kutatások tükrében}

\section{A korai idegennyelv-oktatás sajátosságai és kihívásai a pandémiás idöszakban}

A korai idegennyelv-oktatás átfogó bemutatása túlmutat jelen tanulmány keretein, azonban fontos röviden felvázolni, milyen komplex feladatról van szó, amely nem kis kihívás elé állította a pedagógusokat az online oktatás ideje alatt.

Az idegennyelv-oktatással kapcsolatos modern elvárásoknak egyik központi eleme, hogy nagy hangsúly kerüljön a kommunikációra, ezen belül is a szóbeli kommunikációra, tehát beszédcentrikus legyen. Ez az online oktatás vonatkozásában azt jelenti, hogy fontos szerepet játszanak a szinkron online órák, ahol fejleszthető a beszédkészség és más kapcsolódó kompetenciák, például a pragmatikai ismeretek. Bárdos Jenő ezzel kapcsolatban rámutat, hogy „[...] a módszernél fontosabbnak tünik a motiváltság és a tanári rátermettség. A kommunikatív kurzusok kezdettől fogva használati (és nem grammatikai) »szabályokat « tanítanak, amelyekben figyelembe veszik, hogy ki kivel beszél, milyen helyzetben és milyen stílusban." (Bárdos, 2004, p. 12-13).

A korai nyelvtanulásban kulcsfontosságú a játék, a játékos tanulás aspektusa, amely többek között a motiváció fenntartásában is fontos szerepet játszik (Widlok et al., 2010). Erre az online keret is lehetőséget ad különféle applikációk segítségével. Ugyanakkor a pedagógusoktól nagy időráfordítást és kísérletezést igényel a már bevált játékok online környezetre való adaptálása (N. Kollár, 2020). Nagyon hasonló a helyzet a képek használatával is, melyek szerepe a nyelvtanulás korai fázisában alapvető fontosságú (Widlok et al., 2010). Az internet végtelen számú lehetőséget biztosít ennek kiaknázására, ugyanakkor ennek előkészítése is roppant időigényes online keretek között, illetve több mérlegelési pontot is rejt magában, gondoljunk például a szerzői jogok figyelembevételére, mely Magyarországon még gyerekcipőben jár.

Fontos kitérni még a komplex és több érzékszervet bevonó nyelvi fejlesztés fontosságára kisgyermekkorban (Nauwerck, 2014; Lütgeharm, 2020). Ez volt

\footnotetext{
${ }^{1}$ Az itt szereplő szakirodalmi áttekintés rövidített változata egy nem publikált, kutatási pályázatra benyújtott anyagnak.
} 
az a szempont, melynek megvalósítása talán a legnagyobb kihívást jelentette az online környezetben, hiszen a közös mozgás, éneklés és verselés mind szük keretek közé voltak szorítva az online rendszerek késleltetése miatt.

\section{A pandémia alatti online oktatás eddigi tapasztalatai}

A következő alfejezetben arról esik részletesebben szó, hogy az eddig publikált vizsgálatok milyen tapasztalatokat - nehézségeket és sikereket - tártak fel.

N. Kollár Katalin vizsgálatában, melyet iskolapszichológusok bevonásával és 160 pedagógus részvételével végeztek, több fontos tanulságra világít rá. Kiemeli többek között a pedagógusok alkalmazkodóképességének fontosságát mint a hatékonyság egy meghatározó tényezőjét, a pedagógiai rátermettséget és a módszertani felkészültséget (N. Kollár, 2021). Ezenkívül rámutat arra is, hogy nagy kihívást jelentett a pedagógusoknak annak kialakítása, hogyan tudják az osztályteremben bevált, jól működő gyakorlatokat átvinni az online térbe. Ezzel kapcsolatban a munkaközösségeknek tulajdonít nagy szerepet (N. Kollár, 2021). A vizsgálatból kiderül ezenkívül, hogy a tanárok elégedettek ugyan az online oktatás alatt végzett munkájukkal, de „kevesebb örömet és sikerélményt nyújtott számukra” (N. Kollár, 2021, p. 39). Nádori Gergely ezzel kapcsolatban úgy fogalmaz, hogy a digitális oktatásból a legjobban a tanulás és a tanítás élményszerüsége hiányozhatott. Bármi is történik a képernyőn, az nem ugyanaz, mintha benne vagyunk, részesei lehetünk (Nádori, 2021). Az idegennyelv-oktatásában nagy szerepet játszanak a változatos munkaformák, az együttműködést igénylő feladatok (páros munka, csoportmunka). Ennek fontosságát hangsúlyozza Proháczik Âgnes is, hiszen „a tanulók/hallgatók csak így tudják elsajátítani a társas tevékenységhez szükséges készségeket" (Proháczik, 2020, p. 211). Ezek a munkaformák kevéssé jelentek meg az online oktatás során, ami a diákok magányosságát, illetve magára utaltságát is erősítette (N. Kollár, 2021).

A digitális eszközök használatával kapcsolatban Jakab György megfogalmazza, hogy önmagában az IKT-eszközök használata nem elegendő a minőségi oktatás megvalósításához, bár a használatukhoz kapcsolódó tudás és gyakorlat elengedhetetlen: „A digitális (pala)táblák alkalmazásával ugyan szemléletesebbé lehet tenni az iskolarendszer hagyományos tudásközvetítő módját, de ha ez nem párosul a pedagógiai kultúra radikális átalakításával, akkor lényegi változás csupán az eszközök korszerüsítésétől nem remélhető." (Jakab, 2020, p. 65). Kiemeli, hogy „digitális transzformációnak”, azaz átalakulásnak, átállásnak kell történnie, amely mindenképpen folyamatként értelmezhető (Jakab, 2020, p. 65). Átfogó definíciót találunk ezzel kapcsolatban Racskó Rékánál (2017):

„A digitális átálláson tehát azt a folyamatot értjük, amely során az IKT-müveltség kiteljesedése valósul meg a humán teljesítménytámogató technológia eszközrendszerének alkalmazásával, az információs társadalom technológiái- 
nak (IKT-eszközök) elterjesztése és integrálása révén. Ennek során kiemelt szerepet kapnak az eszközök és azok virtuális környezetei (applikációk, internet), illetve azok a készségek és kompetenciák, amelyek által ezek az elemek magabiztos, kritikus és problémacentrikus alkalmazása valósul meg a tanulás-tanítás céljából, a tartalomhoz való kötöttség nélkül, a megfelelő oktatási célokhoz kapcsolódó új tanulási környezetek kialakításával.” (Racskó, 2017, p. 38).

A fenti idézetben megfogalmazott elvárásokat erősítik meg az IKT-eszközökkel magas szinten foglalkozó gyakorló tanárok is és hangsúlyozzák, hogy akkor érdemes az IKT-eszközök alkalmazása mellett dönteni, ha segítségükkel a tanulók jobban el tudnak mélyedni az anyagban, vagy ha egy problémát kényelmesebben, egyszerübben vagy hatékonyabban oldanak meg, illetve ha hosszabb ideig foglalkoznak egy kérdéssel (Prievara, 2015, 2017).

N. Kollár Katalin rámutat arra is, hogy nemcsak a tanárok digitális kompetenciájának volt és van nagy szerepe az online oktatás során, hanem a diákokénak és sokszor a szülőkének is (N. Kollár, 2021). Malatyinszky Szilárd tanulmányában vizsgálta a pedagógusok tapasztalatait a diákok eszközhasználatával és digitális kompetenciájával kapcsolatban. A következő eredményeket érdemes kiemelni:

„Az értékelések alapján teljes mértékben felkészült a diákok 5,1\%-a, szintén felkészült, de még tanulnia kell ezt az oktatási formát 45,7\%-nak. E több mint 50\%-nyi diák készségszinten tudja használni az eszközöket és nem jelent számukra technikai problémát a megfelelő oktatási tartalmakhoz, felületekhez való hozzájutás. Sok hiányosságot tapasztaltak a diákok 42,2\%-ánál, míg 7\% egyáltalán nem felkészült a digitális oktatásra." (Malatyinszky, 2020, p. 5).

Az eredmények arra engednek következtetni, hogy a tanárok mellett szükséges a diákok digitális kompetenciájának fejlesztése egyaránt, annak ellenére, hogy a most online oktatásban részt vett tanulókat digitális bennszülötteknek szokás nevezni. Ennek a feladatnak a szükségességét hangsúlyozza az OECD PISA-(2018) felmérése is, mely szerint a „magyarországi tanulók mintegy 60\%-a közepesnél lényegesen rosszabbul, vagy egyáltalán nem képes digitális információkat feldolgozni, értelmezni és használni” (OECD PISA, 2018 idézi Proháczik 2020, p. 209). Prievara Tibor (2015) könyvében szintén az itt említett ellentmondásra hívja fel a figyelmet, gondolatait még jóval a járvány kitörése előtt publikálta, de az általa felvetett szempontok jól jellemzik azt a szituációt, amellyel szembe kerültek a pedagógusok az online oktatás bevezetésekor. A diákok online életét az online kommunikáció az írásbeli- és hangalapú chat, az online játék és az online közösségi élet jellemzi (Facebook, Instagram). Az internetes lehetőségek más felhasználási módjait (például közös munka, online prezentáció vagy dokumentumszerkesztés, blogírás) kevésbé ismerik, információkeresésre is csak ritkán használják az internetet, de akkor hatékonyabban, mint a felnőttek. Emiatt a „digitális bennszülött” mítoszát is érdemes lenne újragondolni. 
Összefoglalva elmondható, hogy a pandémiás időszak és ennek tanulságai messzemenőkig megerősítették az élethosszig tartó tanulás relevanciáját és szükségességét. Ez gyakori hivatkozási alap a nyelvtanulással kapcsolatban is.

\section{Digitális eszközök az idegennyelv-tanulásban és -tanításban}

Az IKT-használat bizonyos szinten viszonylag régóta jellemzi az idegenynyelv-tanítást. A modern nyelvoktatás egyik központi kérdése az autentikus (azaz valós környezetben elhangzott, megjelent) anyagok használata, amelyhez gyakran elengedhetetlen valamilyen eszköz. A technika fejlődése iránt érdeklődő és az IKT-eszközök használatára nyitott pedagógusok már a pandémia előtt igyekeztek ezeket bevonni a nyelvtanításba (hiszen ez a nyelvvizsgákra felkészítés és kommunikatív nyelvoktatás alapja), viszont a koranavírus-járvány még soha nem látott módon lendített ezen a folyamaton.

IKT-szakértők már korábban is hangsúlyozták például a virtuális osztálytermek használatának előnyeit. A magyar nyelvü szakirodalmat tekintve Nádori Gergely és Prievara Tibor már 2012-ben publikálták IKT-módszertani ajánlásaikat, melyben a virtuális osztálytermeknek is külön figyelmet szenteltek. Többek között kiemelik, hogy a virtuális osztálytermek a közös munka mellett a szocializációnak is teret engednek, megteremtik az azonnali visszajelzés lehetőségét és a differenciált oktatás is könnyen megvalósítható segítségével (Nádori \& Prievara, 2012). Ezek a virtuális osztálytermek nem képezték széles körben a napi gyakorlat részét a járvány előtt. Az online oktatás első fázisában (2020 tavaszán) is sokszor csak a pedagógus egyéni kezdeményezésére kezdték használni az osztályokban majd a második felvonásban (2021 tavaszán) már sok helyen intézményi szinten döntöttek egyik vagy másik felület mellett. Az intézményi regisztráció nagyban megkönnyítette az adminisztrációs feladatokat és az átláthatóságot is. Az ADOM diákmozgalom által készített nagymintás kérdőíves felmérés ${ }^{2}$ szerint a KRÉTA és a Google Classroom örvendett a legnagyobb népszerüségnek a virtuális osztálytermek közül (Gyetvai, 2020). Ezt az eredményt megerősíti az ELTE kutatói által készített infografika is, amely DiO - Digitális oktatási tapasztalatok (Horváth et al., 2020) címmel online elérhető. Fontos ezzel kapcsolatban megjegyezni, hogy a KRÉTA használata sok helyen kötelező és nem feltétlenül használták virtuális osztályteremként, csupán a feladatok adminisztrálására. Ebben a felmérésben szerepel még a Moodle és az Edmodo mint tanulásmenedzsment-rendszerek (Learning Management System, LMS). Mindkét említett felmérésből látszik, hogy az online oktatás első fázisában még a Facebook és az e-mail is nagy súllyal szerepelt a felhasznált eszközök között.

Szintén nagy népszerűségre tettek szert a korábban szinte csak magánoktatásban használt videokonferencia-szoftverek. Ezekről is elmondható, hogy

\footnotetext{
${ }^{2}$ A felmérés az első bezárás gyakorlatát mutatja, a második fázis valószínűleg még nagyobb népszerüséget mutatna a virtuális osztálytermek használatának tekintetében.
} 
igazán nagy súllyal és széles körben a második bezárás alkalmával kezdték használni a pedagógusok, amikor már nagyobb tapasztalatokkal rendelkeztek arról, mi müködik jól az online térben. Az ADOM által publikált felmérésben a következők szerepelnek ebben a népszerűségi sorrendben (zárójelben a felhasználó válaszadók száma olvasható: Messenger-hívás (1044), Zoom (353), Discord (311), Microsoft Teams (294), Facebook live (135), Skype (91), Google Meet (41), Hangouts (21) (Gyetvai, 2020, 17).

Ahogy az eddig megjelent publikációk is felhívják a figyelmet, ezek a változások önmagukban még nem árulnak el sokat a digitális eszközök használatának minőségéről, illetve az oktatás hatékonyságáról és fejlődéséről. Az eszközök alkalmazásához elengedhetetlen a tudatos pedagógiai tervezés és a módszertani felkészültség (Hirsch, 2020), hogy a modern nyelvoktatás kívánalmainak megfelelően differenciált, az egyéni tanulói igényeket figyelembe vevő, autentikus anyagok és megfelelő eszközök bevonásával működjön a nyelvtanulás.

\section{A pandémiás idöszak utáni (idegennyelv)-oktatás lehetöségei}

A távolléti oktatás egy nagyon pozitív hozadéka az online felületek használata, melyekre az előző fejezetben részletesen kitértünk. A tapasztalatok alapján egyre bátrabban folyamodnak a pedagógusok az online applikációkhoz, melyek nagy könnyedséget jelentettek a távolléti oktatás során. Feltételezhetjük, hogy a jelenléti oktatásban is, az iskolákban rendelkezésre álló készülékekkel továbbra is segítségül fogják a pedagógusok hívni az online felületeket. Egyrészt az órai munkához, másrészt házi feladatok kiosztásához, illetve értékeléséhez. Nagyon nagy valószínűséggel az élet számos területén, így az oktatásban is, tudatosabban, rendszeresebben be fogják vezetni a hibrid megoldásokat (blended learning) is.

Az eddig megjelent tanulmányok is felteszik a kérdést: Mit lehet megtartani az online oktatás során gyüjtött tapasztalatokból? Mi az, ami az osztálytermi tanulás-tanítás során is releváns lehet? Több kutató arra hívja fel a figyelmet, hogy az online oktatás nagy hozadéka a felelősségvállalás a saját tanulási folyamatokért, azaz a tanulói autonómia fejlődése. Prievara (2015) definíciója szerint:

„A tanulói autonómia alatt olyan önszabályozó tanulást értünk, amely nem csupán a tanulási folyamat affektív, kognitív, motivációs és viselkedésbeli szabályozását jelenti. Az autonóm tanuló képes a tanulási folyamat tartalmáért is felelősséget vállalni. Az irányítás ebben az esetben egyre kevésbé lesz a tanár kezében, fokozatosan több beleszólást kell engednünk a diáknak saját tanulási folyamatai szervezésében." (Prievara, 2015, p. 48).

Minden résztvevő tapasztalata lehet, hogy az online oktatás során sok múlott azon, hogy a tanulók mennyire tudták megszervezni a saját időbeosz- 
tásukat, mennyire tudták elosztani a feladatokat és mennyire tudtak navigálni a különböző platformok és applikációk között. Nádori Gergely (2021) arra hívja fel a figyelmet Hogyan tovább? címü blogbejegyzésében ${ }^{3}$, hogy fontos lenne olyan kereteket biztosítani a tanulóknak, amelyek között továbbra is élni tudnak a tempó és az időbeosztás szabadságával. Ez azt is jelenti, hogy partnernek kell tudni tekinteni a tanulókat a tanulásban, ami fontos mérföldköve a felsőfokú tanulmányokra való felkészülésnek, illetve a munkaerőpiacra való belépésnek is. Ebben az összefüggésben fontos fogalom a differenciálás, ugyanakkor vizsgálandó kérdés, hogy mennyiben tudott ténylegesen teret kapni ennek megvalósítása az online oktatás során és milyen jó gyakorlatokat lehetne e téren továbbadni.

\section{A kutatás bemutatása}

\section{A résztvevök és az adatgyüjtés}

A pilotkutatásban öt gyakorló pedagógus és öt negyedéves tanító szakos hallgató vett részt. A gyakorló tanítók átlagos tanítási tapasztalata 19 év. A legtapasztaltabb pedagógus 26 éve, a legfiatalabb 4 éve tanít közoktatásban. A résztvevő gyakorló pedagógusok mindegyike alsó tagozaton, illetve hárman felső tagozaton is tanítanak németet. Egy résztvevő alsó tagozaton más tárgyakat is tanít. A tanítók közül hárman Tolna megyében (két különböző iskolában), ketten Baranya megyében (egy iskolában) tanítanak. Az iskolák közül egy megyeszékhelyen, kettő pedig kisvárosban (10 000 fö alatti városban) található. A megyeszékhelyen található iskola gyakorlóiskola. Egy tanító német kétnyelvü, kettő nemzetiségi nyelvoktató, három pedig idegen nyelvi osztályban tanít. Minden válaszadó nő volt.

A hallgatók mindegyike németes: hárman műveltségterületes, ketten nemzetiségi szakirányos hallgatók. Mindannyian végzős hallgatók, az interjú idején a tízhetes gyakorlatukat végezték. Az interjúban két szerepkörben is nyilatkoztak az online oktatással kapcsolatos tapasztalataikról, tehát hallgatóként és tanítóként is reflektáltak a helyzetre. A megkérdezett hallgatók közül háromnak a gyakorlaton kívül is van már tanítói tapasztalata, az egyetem utolsó évében már elhelyezkedtek, jellemzően napközis tanítóként. Három hallgató budapesti, kettő pedig vidéki iskolában teljesítette a gyakorlatát. A megkérdezettek között négy nő és egy férfi volt.

Az interjúk 2021 áprilisában készültek, többségében még az iskolák bezárása alatt, az utolsó interjút az újranyitás első hetében vettük fel. Az interjúk mindegyike online, különböző platformokon készült. Az interjúk hossza 25 és 51 perc között mozgott.

Az eredmények értékelésénél mindenképpen figyelembe kell venni, hogy önbevallásos válaszokról van szó. A kutatás jelen szakaszában csak a tanítói

\footnotetext{
${ }^{3}$ www.tanarblog.hu
} 
szempontot volt lehetőség megismerni. A kutatás továbbfejlesztésénél mindenképpen szükséges a szempontok bővítése, a minta kiszélesítése, illetve esetlegesen további mérési eszközök bevonása.

\section{Eredmények}

\section{Általános tapasztalatok}

Az interjúk első felében a résztvevők általános tapasztalatai kerültek előtérbe az online oktatással kapcsolatban. Összességében elmondható, hogy a válaszadók benyomásai alapján egy nagyon színes kép rajzolódik ki, intézménytől, tapasztalattól, felkészültségtől függően sokféle szempontot emeltek ki válaszaikban. Elmondható, hogy kevés ismétlődő válasz érkezett, ami a megélés sokszínűsége mellett a kis elemszámnak is köszönhető. A válaszadókban közös volt a téma és más kollégák megoldásai iránt való érdeklődés, a kutatás relevanciájának megerősítése.

A következőkben a pozitív és negatív tapasztalatokról készült áttekintés olvasható. A dőlttel szedett szövegrészek az interjúkból vett idézetek, amelyek az adott szempont szemléltetésére szolgálnak, amennyiben ez releváns.

A válaszadók a következő pozitív tapasztalatokról számoltak be a pandémia miatti iskolabezásárok alatt:

- Új kihívások, sok újdonság megismerése.

"Sok pluszt csináltam, de sok pluszt is adott." / "Egyre rugalmasabb lettem." / "Nem voltam elveszve."

- Technika használata a tanulás során.

"Ha már nyomja a kütyüt, olyanra használja, ami hasznos." / "Láttam, hogy fejlödik."

- Pozitív visszajelzés a tanulóktól, például a használt applikációkkal kapcsolatban.

- Az online oktatás szervezettségi szintje, például iskolaszintü közös tanulási felület bevezetése, tantárgyak redukálása, szinkron órák lehetősége.

- Egyéni szükségletek figyelembevétele, például kevésbé jó technikai infrastruktúrával rendelkező tanulóknak külön feladatok biztosítása.

- Kevésbé változatos munkaformák, viszont olyan szempontok figyelembevétele, amelyek kevésbé markánsan jelentek meg korábban, például IKT-eszközök használata.

- A fegyelmezési problémák hiánya.

A fenti szempontok értékelésénél feltünhet, hogy nem minden pont minősíthető egyértelműen pozitívnak, hiszen megjelenik akár a megfelelő technikai eszközök hiánya, vagy a munkaformák redukálása jellemzően a frontális oktatásra. Az utolsó említett szempont, a fegyelmezési problémák hiánya is további vizsgálatokra szorul, hiszen valószínűsíthető, hogy az új tanulási környezetekben kevésbé váltak láthatóvá bizonyos problémák, amellett, hogy mások viszont valóban eltüntek. Fontos ezenkívül kitérni arra is, hogy 
bár itt egyértelmüen pozitív tapasztalatként szerepel az IKT-eszközök, applikációk, tanulási platformok használata, azonban kutatók hangsúlyozzák, hogy ezek csak megfelelő módszertani felkészültség és tervezőmunka esetén válnak a tanulás és a tanítás igazán hatékony kísérőivé.

A következőkben az inkább negatív tapasztalatként értelmezhető válaszok olvashatóak a pandémia miatti online oktatásról:

- Hiányzó szabályozások a tanulási- és tanítási folyamatban, például a szinkron óráról való hiányzás szankcionálása, késői vagy hiányzó feladatleadás esetei.

- Megnövekedett felkészülési időből fakadó egészségügyi következmények, például bizonyos krónikus fájdalmak kialakulása, látásromlás.

- Hosszú előkészítő folyamat, például a meglévő anyagok digitalizálása, az online oktatásban használható tananyagok keresése, elkészítése, adaptálása, szinkron órákkal kapcsolatos sokrétủ feladatok megoldása.

"Az online oktatás elött tudtam, hogy mikor mihez nyúljak." "Az, hogy az elsős figyelmét lekössem 45 percen keresztül, háromszoros munkámba telik." "Idegenkedtem tôle, bár korábban is használtam." "Nem ad annyi pluszt, úgyis fel kell rakni a Krétába, mert nem tud mindenki csatlakozni."

- A tanulás sikerességének bizonytalansága.

"Nem tudom biztosan, hogy megtanulták-e a szavakat, kijavitották-e a hibákat, lemásolták-e a mondatokat."

- Az időgazdálkodás kérdéskörei, például. akusztikai problémák, mikrofon- és kamerahasználat a szinkron órán.

"Nem érzem magam hatékonynak." / "Ez és ez az anyag, ennek meg kell lennie."

- Technikai nehézségek, a személyesség hiánya.

"Volt olyan, hogy elsírta magát (egy tanuló), mert nem tudta bediktálni a kis pontját."

- Prioritások meghatározása.

"Nem a német az első. Legfontosabb a matek és a magyar."

- Bizonyos nyelvfejlesztési feladatok nehézsége, például a hallásértés feladatok, a differenciálás, a csoportmunka megszervezésének nehézségei.

- A hátrányos helyzetü tanulók bevonása.

- A motiváció fenntartása.

"Most érzékelem, hogy az én saját motivációm lesz egyre kevesebb. Most úgy kell magam ráeröszakolni (a munkára)."

A két listát összehasonlítva megállapítható a negatív tapasztalatok túlsúlya. Ez a jelen kutatásban annyit jelent, hogy többféle nehézséget jelentő szempontot, ide tartozó tartalmat soroltak fel a résztvevő pedagógusok. Pontos képet ebben az esetben is egy nagyobb mintán készült kvantitatív adatelemzéssel, illetve az empirikus adatok további elemzésével kaphatunk.

A válaszokból kiderül, hogy vannak körülmények, amelyek segítették a tanítók online oktatásra való átállását. Példaként említik a digitális eszközökkel kapcsolatos továbbképzéseket, az eszközökkel kapcsolatos korábbi 
tapasztalatokat, az intézményvezetők és az iskola informatika tanárainak segítő hozzáállását, valamint a családi hátteret a tanulók esetében, tehát mind a szülők szocioökönómiai státuszát, mind a szülők technikai felkészültségét.

A korábban már említett kíváncsiság mellett általánosan jellemző volt, hogy a megkérdezettek saját bevallásuk szerint nagy erőfeszítéseket tettek annak érdekében, hogy változatos online órákat tartsanak és érdekessé tegyék az elvégzendő feladatokat. Sok időt fektettek a tananyagok felkutatásába és a tanulást segítő applikációk megismerésébe, valamint gyakorló feladatok előállításába.

\section{Virtuális osztálytermek és LMS-rendszerek}

Az interjúkban külön tematikus egységet alkotott a virtuális osztálytermek, illetve a hallgatók esetében az LMS-rendszerek (mint például az ELTE által előnyben részesített Moodle vagy a Canvas) használata az online oktatás során. Bár a szakirodalom különbséget tesz a két eszköz között, funkciójuk és több tulajdonságuk összekapcsolja őket, ezért itt egy alfejezetben szerepelnek.

A virtuális osztálytermekkel, mint az online oktatás egészével kapcsolatban is pozitív és negatív tapasztalatokat is említenek a pedagógusok, valamint a hallgatók is. A megkérdezettek az alábbi gyakoriság szerint használtak virtuális osztálytermet, illetve videószoftvert az interjú készítésének idejében":

- Google Classroom (5)

- KRÉTA (1)

- Google Classroom és Zoom (2)

- Google Classroom és Google Meet (4) (+ KRÉTA)

- KRÉTA, DKT és Facebook (1)

- Facebook (1)

- Microsoft Teams (3)

A felsorolásból látható, hogy többféle kombinációban használják az említett felületeket a pedagógusok. Jellemzően virtuális osztálytermet és videószoftvert is alkalmaztak, de olyan is van, aki csak virtuális osztálytermet. A Facebook kiegészítő vagy elsődleges eszközként is megjelenik. Ez jellemzően a szülőkkel való kapcsolattartás megerősítésére, illetve olyan hátrányos helyzetű gyerekek esetén volt fontos, akikkel - például eszközhiány miatt - nem volt lehetséges más platformon kapcsolatot tartani. Az eredményekből kiderül, hogy a legnépszerübb eszköz a Google terméke volt. A virtuális osztálytermek kiterjedtebb használata a közoktatási intézmények második bezárásának alkalmával történt meg. Ekkor sok intézmény felismerte, hogy szükség van közös, egységes felületekre mind a tanárok, mind a tanulók terheinek csökkentése érdekében. A válaszokból kiderül, hogy ezt a döntést minden résztvevő üdvözölte, jelentős könnyebbséget jelentett munkájukban, hiszen

${ }^{4}$ Zárójelben a felhasználók száma szerepel. 
az adminisztrációs terhek - például a tanulók feljelentkeztetése a felületekre - egyaránt csökkentek, illetve egyszerübbé vált a folyamat.

A válaszadók a virtuális osztálytermek használatával kapcsolatban a következőket emelték ki:

- Mind a tanulók, mind a tanárok munkája könnyebben kontrollálható.

- A választott felület felhasználóbarát, a szülőknek sem jelent gondot a használat.

- A felület használata precíz, átlátható munkát tesz lehetővé (például feladatok kiosztása, adminisztrálása.

- Nagyobb munkatempót tesz lehetővé.

"Kénytelen azt a mennyiségü anyagot, amit kiszabok, megcsinálni." "Tart a gyereknek 20 percig vagy két napig, de meg kell csinálni." / "Soha életemben a negyedikes könyvet nem csináltam végig."

- Stabil rendszer.

- Komplex rendszer, más funkciókkal szinkronizálható, például naptár ${ }^{5}$.

- Egy egységes rendszer bevezetése után könnyủ segítséget kérni a kollégáktól.

- Sok hasznos funkcióval rendelkezik, például feladatlista - az elvégzett és az elvégzendő feladatokról -, értékelés, csatolmány, határidők kezelése, privát üzenetek.

- Igényes órák megtartását teszi lehetővé.

- Segítségével ugyanaz elvégezhető, mint a jelenléti oktatásban, csak más módon.

- Egyszerre sok résztvevő tud bekapcsolódni.

A számos pozitív tapasztalat mellett nagyjából hasonló súllyal szerepeltek a negatív tartalmú megjegyzések.

- A tesztek automatikus javítási funkciójából fakadó nehézségek.

- Beállítási nehézségek, például a csoportos üzenetküldésnél.

- Az intézményi előfizetés előtt jogi problémákból fakadó nehézségek, például a kiskorú felhasználók miatt.

- Nem elegendő beépített funkció, kifejezetten fiatal tanulóknak.

- A felület kezelésének nehézségei, például a fájl feltöltése.

- Feladatok, szövegek javításának körülményessége.

- Sok csoport esetén hiányzó áttekinthetőség.

- A visszajelzés és az értékelés eszköztára nem elég változatos, például emotikonok versus személyes jelenlét.

- Feladat megértésének ellenőrzése: a visszakérdezés lehetősége jellemzően aszinkron módon történik meg.

A fenti két áttekintésnek nem az a célja, hogy minősítse a piacon elérhető virtuális osztálytermek fejlettségét, sokkal inkább azt hivatott vázolni, milyen szempontokat vesznek figyelembe, illetve milyen szempontok mentén értékelik a választott felületet a pályán lévő tanítók és a tanító jelöltek, tehát

${ }^{5}$ Jellemzően a Google Classroom esetében. 
közvetett módon kiderül, mikor érzik sikeresnek ezek használatát. Összességében elmondható, hogy sokféle szempontot fogalmaztak meg a résztvevők, ugyanakkor az interjúk egy érdekes tapasztalata, hogy a válaszadók nehezen tesznek különbséget a virtuális osztálytermek és egyéb applikációk vagy programok között annak ellenére, hogy az interjú elején minden esetben példákkal illusztrálva tisztáztuk a fogalmat. Ez valószínüleg arra vezethető vissza, hogy a virtuális osztálytermekben sokszor tesznek elérhetővé olyan feladatokat, amelyek más applikációval készültek, sok esetben ezeknek a használata a napi rutinná vált. Az interjúk során szinte minden esetben kérdezés nélkül sorolták fel a válaszadók, milyen más eszközöket használtak a tananyagok színesebbé tételére. Bár ez nem képezte a vizsgálat tárgyát, érdekes fokmérője lehet a tanárok digitális kompetenciájának fejlődésére, az eszközhasználat részletesebb vizsgálata. Egyértelműen a legnépszerübb eszközökhöz tartozik a LeraningApps és a Wordwall, amelyeket a válaszadók többsége említett. Emellett többen éltek a Google Forms felület tesztkészítő lehetőségével. Egy-egy említést kapott a Genially, Wordart, Quizlet, Redmenta és Padlet. Az offline eszközök közül a PPT-prezentáció szerepelt többször, valamint a Screencastify nevü Chrome-alkalmazás.

A hallgatókkal készített interjúk egy fontos kérdése volt, hogy tudott-e profitálni az egyetemen bevezetett online oktatás valamelyik szegmenséből, tudott-e valamit átemelni az ott szerzett tapasztalatokból a saját tanítási gyakorlatába. A megkérdezett öt hallgatóból ketten tudtak ezzel kapcsolatban megfogalmazni valamit. "Nem is gondolkoztam, hogy tudnék-e valamit átvinni." Mindkét válaszadó platformokat és eszközöket emeltek ki, melyek megkönnyítették a tanítást. A Microsoft Teams, a Zoom és a LearningApps adta lehetőségek szerepeltek a válaszokban. Ezenkívül az egyik hallgató kiemelte, hogy az egyetemi kurzusokon volt alkalma hozzászokni a kamera használatához.

A hallgatók az LMS-rendszerekkel kapcsolatban hasonló szempontokat emeltek ki, mint a gyakorló pedagógusok a virtuális osztálytermek vonatkozásában, ugyanakkor ők valamivel kevésbé differenciáltan tudtak reflektálni azok előnyeire, kevés korábbi tapasztalatot tudtak felidézni. Ez a némileg váratlan körülmény más az ELTE TÓK-on zajlott kutatásban is megjelent (ld. Serfőző et al., 2020).

\section{A szülők és tanulók részvétele az online oktatásban}

A vizsgálat részét képezte a pedagógusok nézeteinek feltérképezése a tanulók és a szülők részvételével, illetve szerepével az online oktatásban. Az ebben a kérdéskörben született válaszok az elvárásoknak megfelelően nagyon változatos képet mutatnak. Néhány felmerült szempont beemelésével jól lehet illusztrálni ezt a sokszínűséget.

A pedagógusokban hamar felmerült a kamera bekapcsolásával kapcsolatos elvárás, amely talán minden oktatási kontextusban, közoktatásban és 
felsőoktatásban egyaránt egy sokat vitatott kérdés. A résztvevők körében is felmerült ez az igény, amelyre egyes iskolákban a második lezárás alkalmával reagáltak is és irányelvként fogalmazták meg, hogy amennyiben a tanuló nem kapcsolja be a kameráját, hiányzónak tekintendő. Ennek szükségességét az egyik válaszadó is megerősíti: Ha látom is, akkor tudunk kommunikálni, sokkal emberközelibb. Akkor látom, hogy van értelme.

$\mathrm{Az}$ alsó tagozatos tanulókkal kapcsolatban többen is megfogalmazták, hogy csak kisebb fegyelmezetlenségek merülnek fel, úgy fogalmazott egyikük, hogy még nincs simliskedés. Ugyanakkor felső tagozaton már több problémával kell megküzdeniük a pedagógusoknak, példaként említhető a házi feladat fordítóprogrammal való megoldása, a feladatok elmulasztása (Ellustázták ezt a tárgyat.). Egy válaszadó megfogalmazza, hogy felső tagozaton, akár hatodik osztályban már látszik a feladatok megoldását, hogy nincs ott a szülő, kevesebb segítséget kapnak a gyerekek. Több válaszadó is említett, hogy a gyerekek jól boldogulnak az online oktatás kihívásaival, többen vannak, akik már egyedül próbálják visszaküldeni a feladatokat, feltölteni a szükséges fényképeket (például füzetben elkészített megoldásról). Egy hallgató megjegyezte, hogy a fotók minőségén ez látszik, viszont kifejezi, hogy Örülök neki, hogy próbálkoznak. Az interjúkból kiderül, hogy különösen azok a tanulócsoportok boldogulnak jól, akiknek még a jelenléti oktatás alatt volt lehetőségük megismerkedni a használt felületekkel.

A szülők szerepvállalásával kapcsolatban is van egyfajta kettősség. Sok szülö, aki munkája során is használ digitális eszközöket, jól boldogul, nem okoz számára nehézséget a gyermekek támogatása, ugyanakkor másoknál viszont nagyon kevéssé fejlett digitális kompetenciáról beszélhetünk. Az ilyen esetekben az egyik válaszadó külön szülői konzultációval, képernyőképekkel igyekezett orvosolni a nehézségeket. Előjött a beszélgetésekben az online szinkron órák iránti szülői igény is.

Összességében a megkérdezett pedagógusok mind a gyerekek, mind a szülők szerepvállalását inkább pozitívnak értékelik. Tisztában vannak a helyzet nehézségeivel (Bedobták őket a mélyvízbe, hogy ott tanuljanak meg úszni.) és látják a megtett erőfeszítéseket is (Próbáltak megfelelni.).

\section{Jövőkép}

Az interjúk záró kérdése arra vonatkozott, mit tartanak a résztvevők az online oktatás gyakorlatából megtartásra érdemesnek a jelenléti oktatásban is. Ez az a kérdéskör, amely sok kutatót és a médiát is foglalkoztatja. Az iskolák bezárása alatt gyakran hallható volt az a megállapítás, amely szerint az oktatás örökre megváltozott. Az online oktatás alatt született megoldások nagy hatással lesznek a jelenléti oktatás körülményeire. Az itt bemutatott pilotkutatás alapján az fogalmazható meg, hogy viszonylag nehezen tudtak a résztvevők olyan aspektusokat kiemelni, amelyeket megtartanának a hagyományos oktatásban is. A legtöbbször említett lehetőség az applikációk 
használata volt, például a tankockák készítésére alkalmas LearningApps és a hasonló feladattípusokat kínáló Wordwall. A megkérdezettek ezeket az iskolában is, de kiegészítő feladatként, otthoni megoldásra is szívesen adnák. Kiemelik ezeknek a feladatoknak a motiváló és fejlesztő jellegét.

A virtuális osztálytermek használatát a többség nem tartja szükségesnek a jelenléti oktatásban, összesen hárman utaltak arra, hogy a hiányzó tanulók munkájának segítésére alkalmas lehet, mivel megkönnyíti a kommunikációt, illetve nem jelent túl nagy terhet a szülőnek, hogy követni tudja a házi feladatokat. Egy résztvevő említette, hogy a felületet továbbra is használni lehet tananyagok megosztására, amelyet így nem kell nyomtatni vagy e-mailben küldeni.

A videószoftvereket szintén a hiányzó tanulók bevonására alkalmaznák, de egy-egy említéssel előkerült a versenyre való felkészítés, fogadóórák megtartása, illetve közös délutáni olvasás a gyerekekkel.

Egy pedagógus kifejezetten ellenezte a virtuális osztálytermek jelenléti oktatásban való használatát, véleményét a következőkkel indokolta: Ha mindig felrakjuk oda a leckét, nem fogják megtanulni, hogy fel kell írni. Ezzel kapcsolatban felmerül tehát az autonómia és a felelősségvállalás kérdése is. Érdemes lenne annak a mélyebb vizsgálata, melyik gyakorlat fejleszti jobban a tanulói autonómia kialakulását, illetve beszélhetünk-e egyáltalán erről valamelyik esetben.

\section{Jó gyakorlatok}

Az interjúalanyok beszámolóikban említettek olyan bevált eljárásokat, megoldási lehetőségeket, amelyek nevezhetők „jó gyakorlatoknak”, így külön alfejezetben is érdemes bemutani azokat.

Az egyik hallgató számolt be arról a gyakorlatról, hogy a kötelező órák mellett az iskolában, ahol már tanítóként dolgozik, biztosítanak online napközi foglalkozást is, ahol felügyelet mellett tudják elkészíteni a tanulók a házi feladatukat, ami a szülők terheit is csökkentheti. Ezt követően marad idő kötetlen beszélgetésre is az online alkalom során. Jól illusztrálja ennek szükségességét a hallgató példája, miszerint az egyik tanuló rendszeresen önállóan készítette el a házi feladatot és csak a végén jelentkezett be 20 percre a kötetlen beszélgetés idejére. Egy másik válaszadó is hangsúlyozta, hogy $\mathrm{Na}$ gyon igénylik [a gyerekek], hogy együtt legyenek. Hasonló gyakorlatokat más résztvevők is említettek. Van olyan iskola, ahol rendszeresen közös online meseolvasást tartottak, máshol pedig a tanórák előtt biztosított a pedagógus külön gyakorlási lehetőséget a lemaradással küzdő tanulóknak. Ezenkívül valahol a gyerekek esténként önálló kezdeményezésre kapcsolódnak be egyegy közös beszélgetésbe.

Szintén az egyik hallgató említette, hogy a gyakorlata során sikerült végigvinnie egy projektmunkát, melynek végterméke egy online magazin volt, adaptálva az online oktatásra való átálláshoz. Az együttműködést igénylő fel- 
adatok minden válaszadó szerint háttérbe kerültek ebben a periódusban, így ez a példa további kutatásra is érdemes lenne.

Az online jelenléttel kapcsolatos szabályok sajnos csak kevés esetben kerültek elő a felkészülés során, holott többen is beszámoltak arról, hogy néhány esetben problémát okozott a szinkron órák esetében a chatfunkció vagy a kamera nem megfelelő használata, vagy az óra irányításának átvétele nem megfelelő beállítási paraméterek esetén MS Teamsben. Ezeknek a szituációknak a tisztázására volt olyan iskola, ahol egy ún. netikettet vezettek be, amely tartalmazta az online jelenléttel kapcsolatos viselkedési szabályokat. Mind az osztályfőnökök, mind a szülők feladata volt, hogy beszéljenek ezekről a feltételekről a gyerekekkel. A legtöbb esetben csak akkor merültek fel ezek a szabályok, amikor épp egy konfliktus adódott az óra során.

Szintén fontos momentumnak tekinthető és az interjúk alapján nem általános gyakorlat, hogy az iskola biztosított felkészülési napot az online oktatásra, amelynek keretében a választott virtuális osztálytermet és videószoftvert, illetve a netikettet is megismerték a tanulók.

Nagy segítség továbbá, különösen az alsó tagozat elején járó tanulóknál, ha a szinkron órákon nemcsak az órát tartó tanító van jelen, hanem egy segítő is, aki lehet a napközis kolléga vagy adott esetben a pedagógiai asszisztens vagy hallgató is és elsősorban technikai nehézségek megoldásán dolgozik. Ezek a feltételek sajnos ritkán adottak, ugyanakkor a válaszadó beszámolójából kiderült, hogy ennek nemcsak a jelenléti oktatásban van relevanciája.

Sokan számoltak be arról is, hogy az oktatás jóformán csak a frontális óravezetésre korlátozódott a bezárások alatt, ugyanakkor voltak olyan válaszadók is, akik kiemelték, sikerült megtartaniuk például azokat a rituálékat, amelyek a jelenléti oktatásban már kialakultak, akár az óra eleji mozgás vagy éneklés. A sok változás mellett ezek minden bizonnyal az ismerősség és ezáltal a biztonság érzését tudják erősíteni a tanulókban.

\section{Összefoglalás}

A tanulmány első részében az online oktatás néhány nyelvoktatással kapcsolatos vetülete került előtérbe, így szó esett a korai idegennyelv-oktatás a téma szempontjából releváns sajátosságáról, az eddig publikált tapasztalatokról, a digitális eszközökről, végül pedig a járvány utáni nyelvoktatás lehetőségeiről. A tanulmány második fele egy gyakorló tanítók és végzős tanító szakos hallgatók bevonásával készült kismintás kutatás eredményeiről ad áttekintést. A kutatásban hasonló szempontok jelennek meg, mint jelen írás elméleti, illetve szakirodalmi részében.

Az eredmények azt mutatják, hogy az online oktatással kapcsolatos tapasztalatok nagyon változatosak, sok egyéni megoldás és akár jó gyakorlat is született a megkérdezettek körében. Érdekes, hogy a résztvevők nehezen választják el az online oktatással kapcsolatos fogalmakat, a felhasznált platformok, virtuális osztálytermek, videókonferenciás programok és applikációk 
egy egységet alkotnak válaszaikban. Ugyanakkor a válaszadók saját bevallásuk szerint többnyire sok energiát fektettek abba, hogy érdekes, színes órákat tarthassanak, fejlesszék digitális kompetenciájukat, megismerjenek eszközöket. Elmondható, hogy az online oktatás során a munkaformák változatos használata és a differenciálás eszközei kevésbé jelennek meg. A kooperációt igénylő feladatok a résztvevők véleménye alapján nehezen kivitelezhetőek, nagyon alapos előkészítést igényelnének. Meglepő eredmény, hogy a hallgatók keveset tudtak hasznosítani saját gyakorlatukban abból, amit az egyetemi oktatásban láttak, számukra nehezen összevethető a két tanítási szituáció. Az interjúkból leszürhető kép sok pozitívumot tartalmaz, de nagy hangsúllyal kerülnek elő a problémák is.

Ahogy a bevezetőben már előkerült, az itt bemutatott kutatás csupán egy pilotprojekt, kismintás, egyetlen eszköz és szempont felhasználásával készült, ezért az eredmények korlátozottan használhatóak, mindemellett jó alapul szolgálhatnak egy nagyobb kutatás megtervezéséhez.

\section{Irodalom}

Bárdos, J. (2004). Nyelvpedagógiai tanulmányok. Iskolakultúra (Iskolakultúra Könyvek, 24.) http://mek.oszk.hu/02400/02443/

Buda, A. (2017). IKT és oktatás. Együtt vagy egymás mellett? Belvedere Meridionale. Gyetvai, V./ ADOM diákmozgalom (2020): Felmérés a 2020-as távoktatásról. https:// diakparlament.hu/wp/wordpress/wp-content/uploads/2020/11/Felmeres-atavoktatasrol_ADOM-Diakmozgalom.pdf (2021.05.11.)

Hirsch, N. (2020). Unterricht digital. Methoden, Didaktik und Praxisbesipiele für das Lernen mit Online Tools. Verlag an der Ruhr.

Horváth, L., Czirfusz, D. \& Misley, H. (2020). DiO - Digitális oktatási tapasztalatok: https://create.piktochart.com/output/45101660-dio_report

Jakab, Gy. (2020). Iskola - járvány idején. Iskolakultúra, 30(9), 64-76. https://doi. org/10.14232/ISKKULT.2020.9.64

N. Kollár, K. (2021). Az online oktatás tapasztalatai és gyakorlata a pedagógusok nézőpontjából. Iskolakultúra, 31(2), 23-53. https://doi.org/10.14232/ ISKKULT.2021.02.23

Malatyinszki, Sz. (2020). A digitális oktatás megélése. https://www.researchgate.net/ publication/342378435 (2021.05.09)

Molnár Gy., Turcsányi-Szabó, M. \& Kárpáti A. (2020). Digitális forradalom az oktatásban. Perspektívák és dilemmák. Magyar Tudomány, 181(1), 56-67. https://doi.org/10.1556/2065.181.2020.1.6

Nauwerck, P. (2014). Didaktik und Methodik des frühen Fremdsprachenlernens im Kindergarten. In: Márkus, É. \& Trentinné Benkő, É. (Eds.), A korai idegennyelvi fejlesztés elmélete és gyakorlata: Konferenciaelöadások és háttértanulmányok (pp. 25-48). Eötvös Kiadó. 
Nádori,G.\& Prievara, T.(2012).IKT-módszertan.http://mek.oszk.hu/15900/15959/15959. pdf

Nádori, G. (2021). Hogyan tovább? TanárBlog, 2021. május 5. http://tanarblog.hu/ cikk/hogyan-tovabb (2021.05.09)

Prievara, T. (2015). A 21. századi tanár. Egy pedagógiai szemléletváltás személyes története. Neteducatio Kft.

Prievara, T. (2017). Mi működik és mennyire, 1. rész - a digitális technológiák. TanárBlog, 2017. február 18. http://www.tanarblog.hu/cikk/mi-mukodik-esmennyire-1.-resz-a-digitalis-technologiak (2021. 05. 11.)

Proháczik, Á. (2020). A tantermi és az on-line oktatás (tanítás és tanulás) összehasonlító elemzése. Opus et Educatio, 7(3), 208-219. http://dx.doi. org/10.3311/ope.390

Racskó, R. (2017). Digitális átállás az oktatásban. Gondolat Kiadó/Iskolakultúra.

Serfóző, M., F. Lassú, Zs., Svraka, B. \& Aggné Pirka, V. (2020). Az online térben is az emberi tényezö a legfontosabb. Hallgatói visszajelzések a távolléti oktatásról. https://www.tok.elte.hu/dstore/document/1140/T\%C3\%81VOK\%20 r\%C3\%B6vid\%20besz\%C3\%A1mol\%C3\%B3_k\%C3\%A9sz.pd ([2021.05.11.)]

SchoolEducationGateway: Felmérés az online tanulásról és a távoktatásról eredmények (2020). https://www.schooleducationgateway.eu/hu/pub/viewpoints/ surveys/survey-on-online-teaching.htm (2021.05.11.)

Widlok, B., Petravić, A., Org, H. \& Romcea, R. (2010). Nürnberger Empfehlungen zum frühen Fremdsprachenlernen. Neubearbeitung. Goethe Institut. 


\section{Miskei-Szabó, R.}

\section{Experience of online teaching from the perspective of primary school teachers and university students. The role of virtual classrooms in teaching}

This study examines primary school teachers' and university students' experience of online teaching during the restrictions caused by the COVID 19 pandemic in 2020-21. This study is based on a small-sample. Data from the interviews give an insight into the general experience of the participants, the functioning of virtual classrooms, and the future role of platforms and tools introduced during online teaching.

Keywords: Covid19, online teaching, language teaching, virtual classrooms

Miskei-Szabó Réka: https://orcid.org/0000-0002-6714-379X 